\title{
A PREFACE TO AN INCLUSIVE AFRICAN ELECTORAL SYSTEM REFORM AGENDA ${ }^{1}$
}

\author{
Mohamed Salih \& Abdalla Hamdok
}

Mohamed Salih is Professor of Development Politics at the ISS, University of Leiden, Department of Political Science

P O Box 9555, 3200RB, Leiden

Tel: +31 715273 902; Fax: +31 715273815

e-mail: salih@fsw.leidenuniv.nl

Institute of Social Studies, P O Box 29776, 2502LT, The Hague

Tel: +31 704260 573; Fax: +31 704260799

e-mail: salih@iss.nl

Abdalla Hamdok is Regional Director for Africa and the Middle East, International IDEA, Suite 55 Private Bag X1, Menlo Park 0102, Pretoria

Tel: +27 12460 5305; Fax: +27 123462581

e-mail: a.hamdok@idea.int

\begin{abstract}
The main purpose of this paper is to contribute to a better understanding of why African electoral systems should be reformed and how to do so in order to improve the quality of representation, participation, and government effectiveness. We attempt to offer a generic framework, a menu, so to speak, whereby African political parties and policy makers can reflect on the current state of play vis-à-vis their electoral systems and then decide whether a comprehensive or partial electoral reform agenda is needed. The paper also delineates the various institutions and stakeholders that should be involved in the electoral system reform process. This is a call to improve the reform process instead of entrusting it with a limited range of state-sponsored institutions, which often create more problems than those they contrive to solve.

The paper is divided into four sections: a) a synoptic exposé of electoral reforms; $b$ ) the various types of electoral reforms and the factors which militate against them; c) lessons from the African experience with electoral system reforms; and d) an analysis of the main stakeholders required to steer a comprehensive electoral system reform agenda.
\end{abstract}

1 The views expressed in this paper are those of the authors and do not necessarily represent the views of International IDEA or the ISS. 


\section{INTRODUCTION}

Critics of the conduct of African elections are concerned with at least two types of structural deficiencies emanating from the quality of democracy. The first is the electoral formula (or system) applied in an overall socio-economic context characterised by poverty, patronage and severe social, ethnic, religious, cultural, and linguistic cleavages, the second the technical deficiencies, often informed by structural problems emanating from inadequacies related to constituency size, balloting, and the conduct of election administration.

It is difficult, even impossible, to make any headway in improving the quality of democratic practice without taking electoral system reform very seriously. It is important to stimulate discussion about an inclusive reform agenda not only because this is an area in which field-based studies are in short supply but also in order to promote effective policy-making in this field. The following factors justify the need for a preface such as this:

- Some African countries are in the formative stages of competitive democratic politics having only recently done away with one-party systems or authoritarian, military or military-civilian rule. Most of the problems they have experienced have related to the electoral system they have chosen.

- Although some African countries (eg, Botswana, Burkina Faso, Mauritius, Senegal) have had a longer experience with competitive democratic electoral politics than others, many of them still encounter democratic deficiencies emanating from electoral system inadequacies.

- The same applies even to those hailed as beacons of hope for democracy.

- There is strong correlation between political violence, instability, and democratic deficit, on the one hand, and the quality of electoral systems, on the other.

For these reasons we hope this preface will plug into some grey areas in Africa's democratic experience. We return to these important issues in Table 1.

Electoral system reforms are either dictated by political crises (eg, Nigeria, Kenya, Lesotho, Sierra Leone, Liberia, Sudan, Togo) or by stable democratic developments recognised by the political leadership, political parties and other stakeholders. In both cases, the need for reform is treated as an instrument for improving the quality of the democratic practice. 


\section{ELECTORAL SYSTEMS}

Narrowly defined, an electoral system consists of a set of rules for conducting an election and the legal and administrative framework and procedures adopted for translating votes into seats. The rules and framework are informed by three broader issues: the scope of the elected office (which offices are subject to elections); the extent of the franchise (who has the right to vote); and voter turnout (who does vote) (Hague, Harrop \& Breslin 1998, p 100). With regard to the first, the more offices that are elected in a process of free and fair elections, the more competitive the political system and hence the more democratic. In relation to who should vote, in most countries every citizen older than 18 has the right, regardless of sex, religion or race. The third factor relates to the number of enfranchised voters who elect to use their vote - universal suffrage does not guarantee that citizens actually go to the polling stations and cast their vote.

Election administration institutions, laws, rules, and regulations, including seemingly mundane issues, are as vital to the operation of an electoral system as the choice of the system itself. Each electoral system is governed by an independent national electoral commission; judicial and electoral petition tribunals; rules for electoral administration; constitutional provisions or basic electoral laws or regulations; registration of political parties and voters; delimitation of constituencies; establishment and equipping of polling stations; overseeing election campaigns and funding; procurement, custody, security and distribution of election materials, equipment and venues; administration and processing of primaries and campaigns; and vigilance and prudence on election day. In short, even a perfect electoral system (if it has ever existed) can fall victim to imperfections generated during the technical processes of election administration.

These aspects of the electoral system can be summarised by three practical or technical considerations:

- Constituency structure: single-member, multi-member, number of seats per constituency, based on the existing administrative structure or nation-wide.

- Ballot structure: Is the vote about the parties or the candidates; who selects the candidates - the party or the party electoral college or party members? Is the system based on a closed or open list ballot?

- The electoral formula: The basic options are: plurality (the party/ candidate with most votes wins), majority (the party/candidate with more than 50 per cent of the vote wins), proportional representation (PR) (seats are distributed on the basis of votes obtained), and mixed (a combination of PR and majority or plurality).

Massicotte, Blais \& Yoshinaka 2004 
More broadly, electoral systems echo much of Dahl's concept of a competitive democracy, including: elected officials or deputies; free and fair elections; inclusive suffrage; the right to run for office; freedom of expression; alternative sources of information; and associational autonomy (Dahl 1989, p 221). The choice of an electoral system is crucial for the functioning of democracy, particularly if it is informed by the socio-economic and political environment within which it is implemented.

According to Heywood (2002, p 232) an electoral system is a set of rules that govern the conduct of elections. Not only do these rules vary across the world, they are also, in many countries, the subject of fierce political debate and argument. They vary in a number of ways:

- Voters may be asked to choose between candidates or between parties.

- Voters may either select a single candidate or vote preferentially, ranking the candidates they wish to support in order.

- The electorate may or may not be grouped into electoral units or constituencies.

- Constituencies may return a single member or a number of members.

- The level of support required to elect a candidate varies from a plurality (the largest single number of votes or a relative majority) to an overall or absolute majority or a quota.

These five considerations are important because they inform the overall electoral system, whether it is a majoritarian system such as a single-member plurality system (first-past-the-post - FPTP), whereby the part which wins the larger number of votes wins the elections and forms the government, or a proportional system, which guarantees a more equal relationship between the seats won by a party and the votes won in the election.

Put more succinctly by Blais \& Massicotte (2002, p 41):

There are three basic electoral formulas, corresponding to as many criteria in legitimacy as to what is required to be elected. Supporters of plurality are satisfied when a candidate gets more votes than each individual opponent, while others think that one should be declared a winner only when he or she can muster half of the votes, that is, a majority. Advocates of proportional representation feel that political parties should be represented in parliament in exact (or nearly exact) proportion to the vote they polled. Mixed systems combine PR with either plurality or majority. 
Working with or striving to reform any of the three basic formulae is important for political parties and the representivity and/or stability of the government they produce. This is largely because electoral systems determine party performance in and chances of winning elections and thus to hold power and to form and control the resources and personnel of government for the public good.

To this extent, the attitude of political parties to electoral systems is determined by whether the system that is adopted gives them certain advantages over their opponents. As a rule, parties prefer to retain the electoral system that is advantageous to them and campaign to reform the system that is disadvantageous to them.

Heywood (2002) laments:

The electoral reform debate is, at heart, a debate about the desirable nature of government and the principles that underpin 'good government' ... Electoral systems therefore merit only a qualified endorsement, reflecting a balance of advantages over disadvantages and their strength relative to other systems. These criteria fall into two general categories: Those related to the quality of representation, and those linked to the effectiveness of government.

Therefore electoral system reforms have to do with how to make democracies respond to the thorny questions of how to ensure that a democratic representative government is a good government in itself, and that it has been elected by rules that guarantee a democracy characterised by competition, inclusiveness and political participation, and guarantees of civil and political liberties.

According to International Institute for Democracy and Electoral Assistance (IDEA) (Reynolds \& Reilly 1997, p 9), the criteria for crafting an electoral system should ideally include some or all of the following key considerations, which are also dependent on the socio-economic and political environment within which the electoral system is implemented. The considerations are:

- ensuring a representative parliament;

- making elections accessible and meaningful;

- providing incentives for conciliation;

- facilitating stable and effective government;

- holding government and representatives accountable;

- encouraging 'cross-cutting' political parties;

- promoting a parliamentary opposition;

- cost and degree of administrative effectiveness. 
These eight key considerations carry different weights in different democratic contexts and should therefore be adapted rather than used as a blueprint at the onset of crafting electoral systems or when an electoral system fails to achieve the main objectives for which it was originally designed.

\section{WHAT TYPES OF ELECTORAL SYSTEM REFORM AND WHY?}

Electoral reforms refer to the processes by which citizens' participation in a democracy is governed. The list of what actually constitutes these reforms is long. It includes:

- reforming or changing the existing electoral system, for example, from FPTP to PR, or introducing a hybrid system;

- altering the rules governing the election of the legislature or executive;

- changing the regulations governing partisan monitoring of elections or supplementing monitors with non-partisan (national or foreign) observers;

- reforming or replacing the existing election law;

- redefining citizens' eligibility to vote;

- changing the rules governing ballot access;

- delimiting, increasing, or changing constituencies and districts;

- designing and implementing a new ballot system;

- using new voting and vote-counting methods and technology;

- introducing and enforcing election campaign regulations or laws.

Most of Africa's electoral reforms in the late 1980s and the early 1990s were concerned with the transition from one-party systems, military socialism, military or civil dictatorship to multiparty democracy, which necessitated broad and allembracing reforms. Those reforms were part of a broader political process aimed at democratising authoritarian regimes and transforming them into democratic ones. The major African debates during the onset of the democratisation process centred on issues of how to effect the constitutional reforms necessary to change the electoral law and also the introduction of most or all of the constituents of electoral system reforms cited above.

In the same vein, the victorious liberation movements - the African National Congress (ANC) in South Africa, the Ethiopia Peoples Revolutionary Democratic Front (EPRDF), the South West Africa Peoples Organization (SWAPO), the Eritrean Peoples Liberation Front (EPLF), the Rwanda Patriotic Front (RPF), the Front for the Liberation of Mozambique (Frelimo), the Sudan People's Liberation Movement/Army) (SPLM/SPLA) - conceived and implemented reforms to the 
electoral system within the broader realm of restructuring the state and transforming an unjust political order. In all these countries new constitutions have been designed or engineered in order to respond to the new political reality and, with the exception of Eritrea, all of them, most recently the Sudan with its new Political Party Law (2006), have adopted and implemented multiparty democracy.

For yet another group of countries, electoral reforms meant replacing restrictive electoral laws with laws intended to improve representation; addressing issues pertaining to injustice in the allocation of constituencies; nation-building (ie, improving regional, ethnic, linguistic or minority representation in national or regional institutions); increasing the participation of women in politics by assigning quotas for women; or making changes in the constitution and/or in electoral or political party laws. In Southern Africa this impetus to change has been the result of the combined efforts of the member states and the Southern African Development Community (SADC) and some states have fared better than others.

It would be a grave mistake to assume that electoral reforms are the solution to political problems expressed in terms of dissatisfaction with the existing electoral system and to hope that these problems will disappear once the electoral system is reformed. In most cases, electoral systems become entrenched and those parties which benefit from the existing system tend to reject reform, while losing parties agitate for reform in order to improve their electoral chances. The African experience with electoral reforms magnifies what Cox (1997, p 16) referred to as the incompatibility of institutional and social determinants which inform the capacity of electoral systems to activate the formation of political cleavages independent of strong social cleavages based on ethnicity, culture, language, and other attributes. Such attributes, we hasten to add, might stifle the reforms and produce election results similar to those the election system designers are attempting to change. ${ }^{2}$

Electoral system reforms are, at best, about redefining the losers and winners and improving the chances of those who feel aggrieved by elements of the existing system which narrow their electability. In a deeper sense, electoral system reforms are about power shifts by electoral design which, like all power shifts, may engender turbulent political events and instability, particularly in cases when the prevailing political system has coincided with the entrenchment of structural inequality

2 See Norris (2004) for a more comprehensive comparative debate about how voters respond to changing the rules of the electoral game, contrasting rational choice institutionalism and cultural modernisation theories. 


\section{LESSONS FROM EXPERIENCE}

We argue in the introduction to this paper that African electoral system reforms are dictated either by political crises or peaceful democratic transition whose necessity is recognised by the political leadership, political parties, and other stakeholders. In this section we introduce the electoral reform experiences of ten African countries. Unfortunately, without exception, the electoral system reforms in all ten countries were dictated by political crises, some peaceful, some violent. The issues addressed are consistent with the overall factors (shown in Table 1), which militate for electoral system reform in other countries as well.

Table 1 indicates that similar problems confront most African multiparty competitive democracies. They centre on electoral reforms issues, which, if they remain unresolved, together create a serious credibility problem for the quality of African democracy.

Table 1

Major Issues Addressed by Electoral System Reform in 10 African Countries.

\begin{tabular}{|l|l|}
\hline Country & \multicolumn{1}{|c|}{ Issues addressed } \\
\hline Botswana & 1. Electoral participation and competition \\
\hline & 2. Party system integrity \\
\hline & 3. Electoral law \\
\hline & 4. Campaign finance \\
\hline Burkina Faso & 1. Electoral participation and competition \\
\hline & 2. Party system integrity \\
\hline & 3. Electoral law/campaign finance \\
\hline & 4. Election administration \\
\hline & 5. Election management body (EMB) independence \\
\hline Ethiopia & 6. Election monitoring \\
\hline & 1. Electoral participation and competition \\
\hline & 2. Party system integrity \\
\hline & 3. Political violence \\
\hline
\end{tabular}




\begin{tabular}{|c|c|}
\hline & 5. Electoral law/campaign finance \\
\hline & 6. Election administration \\
\hline & 7. EMB independence \\
\hline & 8. Election monitoring \\
\hline \multirow[t]{7}{*}{ Egypt } & 1. Electoral participation and competition \\
\hline & 2. Party system integrity \\
\hline & 3. Political violence \\
\hline & 4. Election violence \\
\hline & 5. Electoral law/campaign finance \\
\hline & 6. Election administration \\
\hline & 7. Election monitoring \\
\hline \multirow[t]{7}{*}{ Lesotho } & 1. Electoral participation and competition \\
\hline & 2. Party system integrity \\
\hline & 3. Political violence \\
\hline & 4. Election violence \\
\hline & 5. Electoral law/campaign finance \\
\hline & 6. Election administration \\
\hline & 7. Election monitoring \\
\hline \multirow[t]{8}{*}{ Kenya } & 1. Electoral participation and competition \\
\hline & 2. Party system integrity \\
\hline & 3. Constitution Review Commission \\
\hline & 4. Political violence \\
\hline & 5. Election violence \\
\hline & 6. Electoral law/campaign finance \\
\hline & 7. Election administration \\
\hline & 8. Election monitoring \\
\hline Nigeria & 1. Electoral participation and competition \\
\hline
\end{tabular}




\begin{tabular}{|l|l|}
\hline & 2. Party system integrity \\
\hline & 3. Political violence \\
\hline & 4. Electoral law/campaign finance \\
\hline & 5. Election administration \\
\hline South Africa & 6. Election monitoring \\
\hline & 1. Electoral participation and competition \\
\hline & 2. Party system integrity \\
\hline Sudan & 3. Political violence \\
\hline & 1. Electoral participation and competition \\
\hline & 2. Party system integrity \\
\hline & 3. Political violence \\
\hline & 4. Election violence \\
\hline & 5. Electoral law/ campaign finance \\
\hline & 6. Election administration \\
\hline & 7. EMB independence \\
\hline & 8. Election monitoring \\
\hline & 1. Electoral participation and competition \\
\hline & 2. Party system integrity \\
\hline & 3. Political violence \\
\hline & 4. Election violence \\
\hline & 6. Electoral law/campaign finance \\
\hline & 7. EMB independence \\
\hline & Election monitoring \\
\hline & \\
\hline &
\end{tabular}

Source: Compiled from various sources, notably ACE/IDEA Electoral Knowledge Database <aceproject.org/electoral-advice/ace-network-facilitators-policy-specialists>;

Electoral System Design <www.idea.int/esd/>;

Funding of Political Parties and Election Campaigns $<$ www.idea.int/publications/ funding_parties/index.cfm> 
However, these problems are more significant in some countries than in others. In other words, while Burkina Faso, Egypt, Ethiopia, Kenya, Lesotho, Nigeria, Sudan, and Togo have more than their fair share of democratic deficit defined by the number of issues either addressed or pending, Botswana (four issues) and South Africa (three) share the least of these concerns, but for different reasons.

In South Africa, the ANC's electoral success has created a dominant-party system which is subject to criticism by those who lost out in the electoral process. Botswana has the longest-serving 'liberal democratic' competitive electoral political party, which depends on the support of the largest ethnic group (the Tswana), making the relationship between ethnicity and voter behaviour an obvious target of criticism. Party dominance in Botswana and South Africa entices the ruling parties to be complacent and less responsive to opposition demands, even where the opposition has genuine concerns about the way in which public affairs are governed.

Table 1 also illustrates that the issues bedevilling electoral reform involve various stakeholders and not merely the national electoral commissions, the legislature or the political executive. If electoral reforms are to have any hope of success they should chart the major areas of concern, enlisting an even more elaborate checklist of issues to be addressed than the generic ones listed above.

That the multitude of stakeholders involves diverse issues and competing interests, making electoral reform inclusive means that a political space for stakeholder participation should be created deliberately. Although it is unrealistic to imagine that all stakeholders will agree on all aspects of the reform agenda, the fact that contentious issues are debated openly, as they should be in democratic societies, will make the end-product transparent and even induce those who were against certain aspects to work within the broad framework.

\section{MAJOR STAKEHOLDERS IN ELECTORAL SYSTEM REFORM}

Judging from some recent turbulent electoral reform experiences in Africa it is obvious that in most cases the stakeholders are narrowly defined as the electoral commission, the legislature, and the political executive. Opposition political parties were given token representation, enabling the governing party to overrule them. In this section we elucidate the major stakeholders in the electoral reform process and what their functions are.

These stakeholders and functions are outlined in Table 2. However, the table may give the impression that the stakeholders operate in isolation, with each group safeguarding its interests by trying to ensure that the electoral system it prefers prevails over the others. For example, although national election commissions are independent, in some countries the president or prime minister 
requests the Speaker of Parliament or the National Assembly to table certain legislation (such as election law or electoral reform) or to organise referenda before starting the consultation process leading to the promulgation of the new legislation.

Table 2

Major Stakeholders in the Electoral System Reform Process

\begin{tabular}{|c|c|}
\hline Stakeholder & Role \\
\hline The executive & $\begin{array}{l}\text { Although in most countries members of } \\
\text { Parliament can sponsor Bills, which are } \\
\text { often named after them when they are } \\
\text { passed, in states characterised by executive } \\
\text { branch dominance, the prime minister or } \\
\text { the president, in consultation with the } \\
\text { Speaker of Parliament, works with Parlia- } \\
\text { ment to set in motion the electoral system } \\
\text { reform process. Once the process com- } \\
\text { mences the executive branch withdraws } \\
\text { and leaves the work to the independent } \\
\text { national electoral commission. }\end{array}$ \\
\hline $\begin{array}{l}\text { Independent national electoral commission } \\
\text { (INEC) }\end{array}$ & $\begin{array}{l}\text { The INEC is an independent constitutional } \\
\text { body subject in the exercise of its functions } \\
\text { only to the Constitution and any other law. } \\
\text { It should therefore be above partisan } \\
\text { politics and should not take sides in } \\
\text { determining the outcome of the con- } \\
\text { sultations leading to electoral system } \\
\text { reforms. } \\
\text { Other functions include: } \\
\text { - overseeing and coordinating the } \\
\text { efforts of the various stakeholders } \\
\text { and making sure that they are } \\
\text { properly recorded; } \\
\text { - preparing the necessary } \\
\text { documentation, which requires it to } \\
\text { be informed about the electoral } \\
\text { system; }\end{array}$ \\
\hline
\end{tabular}




\begin{tabular}{|c|c|}
\hline & $\begin{array}{l}\text { developing a timetable for the } \\
\text { duration of the deliberations } \\
\text { with a clear plan of action of how } \\
\text { the reform process will be } \\
\text { implemented; } \\
\text { - developing an information and } \\
\text { communications strategy to } \\
\text { ensure transparency and } \\
\text { accountability. }\end{array}$ \\
\hline $\begin{array}{l}\text { Opinion leaders (chiefs and clergy, } \\
\text { intelligentsia, former heads of states, etc) }\end{array}$ & $\begin{array}{l}\text { These groups bring into the democratisation/ } \\
\text { reform process the voice of reason and } \\
\text { moderation. Such a role is crucial, particularly } \\
\text { at times of crisis and transition. }\end{array}$ \\
\hline $\begin{array}{l}\text { Special interest groups (women, youth, } \\
\text { the elderly and underrepresented districts) }\end{array}$ & $\begin{array}{l}\text { Special interest groups articulate the particular } \\
\text { interests of the group and contribute to } \\
\text { addressing them. }\end{array}$ \\
\hline Media and information sector & $\begin{array}{l}\text { The media and information sector provides for } \\
\text { the creation of a transparent environment and } \\
\text { plays the role of watchdog over all other } \\
\text { branches of governance. }\end{array}$ \\
\hline Democracy and human rights lobby groups. & $\begin{array}{l}\text { Democracy and human rights lobby groups } \\
\text { play an important role in making sure that } \\
\text { issues of human rights are addressed. }\end{array}$ \\
\hline Civic education experts & $\begin{array}{l}\text { Civic education experts help in the process of } \\
\text { educating the public about its rights and } \\
\text { obligations. They also contribute to the } \\
\text { creation of public awareness and under- } \\
\text { standing of the issues involved. }\end{array}$ \\
\hline $\begin{array}{l}\text { Minorities (eg, ethnic, religious, } \\
\text { regional, demographic) }\end{array}$ & $\begin{array}{l}\text { In pluralistic societies minorities play an } \\
\text { important role in the articulation of the } \\
\text { interests of their respective groups. The } \\
\text { reciprocal roles of minorities and dominant } \\
\text { groups determine whether societies will be } \\
\text { stable or experience continuous conflict. }\end{array}$ \\
\hline $\begin{array}{l}\text { Constitution/electoral system/election } \\
\text { law experts }\end{array}$ & $\begin{array}{l}\text { Electoral reforms and election or political party } \\
\text { laws elaborate on certain constitutional } \\
\text { provisions; some are in fact by-laws. Ensuring } \\
\text { consistency will eliminate wrangling between }\end{array}$ \\
\hline
\end{tabular}




\begin{tabular}{|c|c|}
\hline & $\begin{array}{l}\text { competing interests, with one using the } \\
\text { constitution, the other the electoral law. } \\
\text { Electoral system design is essentially a } \\
\text { technical process determined by political } \\
\text { consultation. Knowing both in theory and } \\
\text { practice the advantages and disadvantages of } \\
\text { the systems being debated is essential and } \\
\text { requires certain expertise. Countries should } \\
\text { either establish a technical committee of } \\
\text { experts to advise on any controversial matters } \\
\text { that may arise or should have experts } \\
\text { embedded in the INEC. In countries where the } \\
\text { independence of the INEC is in doubt, an } \\
\text { autonomous technical expert may be } \\
\text { recommended. }\end{array}$ \\
\hline Census experts and surveyors & $\begin{array}{l}\text { The role of census experts and surveyors is } \\
\text { crucial when the intended electoral reforms } \\
\text { involve delimiting, changing, or creating new } \\
\text { constituencies which might affect negatively } \\
\text { the fortunes of some political parties. Instead } \\
\text { of leaving this issue to the manipulative skills } \\
\text { of politicians, census experts, working as } \\
\text { technicians, are expected to endow the } \\
\text { constituency delimitation process with } \\
\text { legitimacy. }\end{array}$ \\
\hline Legislature & $\begin{array}{l}\text { The role of the legislature in the electoral } \\
\text { process is to provide the legal or policy } \\
\text { initiative and to deliberate and legislate after } \\
\text { consultations are completed. }\end{array}$ \\
\hline The general public & $\begin{array}{l}\text { Because the major object of electoral reforms } \\
\text { is to ensure participation, inclusivity, and the } \\
\text { integrity of the electoral process, the parties } \\
\text { and party leadership, its ultimate goal is to } \\
\text { address the public's (the voters') general } \\
\text { concerns. Another major reason why the } \\
\text { public should be involved through its repre- } \\
\text { sentative institutions and also through a } \\
\text { steady flow of information is to bolster its trust } \\
\text { in politics. }\end{array}$ \\
\hline
\end{tabular}


In the past some electoral system reforms have been beset by serious problems when the executive branch has interfered in the consultation process, circumvented the independence of the INEC, or expressed strong opinions about the outcome of the consultation process before it has even begun.

Such cases are reminiscent of one-party regimes or regimes characterised by extreme executive dominance. In all such cases the opposition, supported by democracy and human rights activists and some opinion leaders, legislators, regional and sub-regional and international election observation missions, have cried foul, dubbing the process cooptive rather than participative.

Obviously, the need for an inclusive electoral reform agenda necessitates adherence to a multiple-stakeholder approach which safeguards against the monopoly by a few interest groups of the agenda-setting process and outcome, which may disfranchise others and lead to its rejection, at best, and political violence, at worst.

Operating within the framework of an inclusive electoral system reform agenda is an exercise in democracy, whereby multiple-problem-solving scenarios are discussed in a transparent and participatory manner. The outcome, in our view, is superior to narrow-based electoral system reform agendas, no matter how technically sound they might be.

\section{CONCLUSION}

Electoral system reforms are central to improving the quality of democracy in Africa, where, in the main, the FPTP system has resulted in less political stability and more conflict. The idea that changing to a PR system will immediately redress the inadequacies of FPTP has also been challenged. Increasingly, advocates of plurality-PR hybrids believe they bring together the best of two worlds, thus arguing against Sartori's (1994) contention that hybrid systems probably combine the deficits of both. Recent African examples (Guinea, Lesotho, Senegal, Seychelles and Tunisia) have shown that these countries have become more politically stable with the introduction of mixed or hybrid systems.

However, we argue that the quality of a country's democracy cannot be attributed solely to the quality of its electoral system, though by-and-large, electoral systems such as PR and mixed member PR play a significant role in accommodating political grievances emanating from inadequate representation of minorities, women, and other socially disadvantaged groups.

We argue that electoral system reform may not produce the intended results if experience is not taken into account. Either way, electoral reform is more than a reform of the election laws and the delimitation of old and new constituencies, although these are vitally important. 
Therefore, electoral system reform is about shaping a democratic process that can challenge entrenched ethnic, religious, regional, class, or gender interests in the struggle to produce inclusive, representative, accountable, and transparent political institutions. It is also about how multiple stakeholders vie to protect their interests and how the process can be hijacked if it is not participatory, transparent, and inclusive.

\section{- REFERENCES -}

Blais, A \& K Massicotte. 2002. 'Electoral Systems'. In L Leduc, R G Niemi \& P Norris. Comparing Democracies 2: New Challenges in the Study of Elections and Voting. London: Sage Publications.

Cox, G W. 1997. Making Votes Count: Strategic Coordination in the World Electoral Systems. Cambridge: Cambridge University Press.

Dahl, R. 1989. Democracy and its Critics. New Haven: Yale University Press.

Hague, R, M Harrop \& S Breslin. 1998. Comparative Government and Politics. Basingstoke: Macmillan.

Heywood, A. 2002. Politics. Basingstoke: Macmillan.

Leduc, L, R G Niemi \& P Norris. 2002. Comparing Democracies 2: New Challenges in the Study of Elections and Voting. London: Sage Publications.

Mair, P. 2002. 'Comparing Party Systems'. In L Leduc, R G Niemi \& P Norris. Comparing Democracies 2: New Challenges in the Study of Elections and Voting. London: Sage Publications.

Massicotte, L, A Blais \& A Yoshinaka. 2004. Establishing the Rules of the Game: Election Laws in Democracies. Toronto, Buffalo, London: University of Toronto Press.

Mohamed Salih, M A. 2003. African Political Parties: Evolution, Institutionalization and Governance. London: Pluto.

— \& P Norlund. 2007. Political Parties in Africa: Challenges of Sustainable Partybased Democracy. Stockholm: International IDEA.

Norris, P. 2004. Electoral Engineering: Voting Rules and Political Behavior. Cambridge: Cambridge University Press.

Reynolds, A \& B Reilly. 1997. Electoral System Design. Stockholm: International IDEA.

Sartori, G. 1994. Comparative Constitutional Engineering: An Inquiry into Structures, Incentives and Outcomes. London: Macmillan.

Schmidt, M G. 2002. 'Political Performance and Types of Democracy: Findings From Comparative Studies'. European Journal of Political Research 41. 